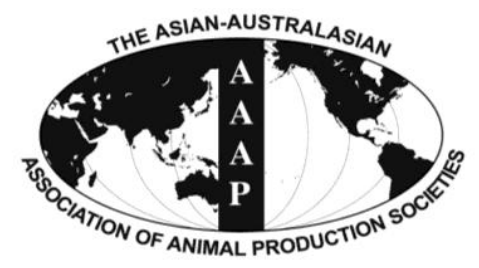

Asian-Aust. J. Anim. Sci.

Vol. 25, No. $8: 1190$ - 1196

August 2012

www.ajas.info

http://dx.doi.org/10.5713/ajas.2012.12019

\title{
Comparative Analysis on Antioxidative Ability of Muscle between Laiwu Pig and Large White
}

\author{
Wei Chen, Hong-Lei Zhu, Yuan Shi, Meng-Meng Zhao, Hui Wang and Yong-Qing Zeng* \\ College of Animal Science, Shandong Agricultural University, Tai'an, Shandong 271018, China
}

\begin{abstract}
This study was conducted to evaluate effects of storage temperatures $\left(4^{\circ} \mathrm{C}\right.$ and $\left.20^{\circ} \mathrm{C}\right)$ and pig breeds (Laiwu pig and Large White pig) on the main antioxidative enzymes (superoxide dismutase, catalase, and glutathione peroxidase) activity and lipid oxidation in porcine Longissimus dorsi muscle. Activities of antioxidative enzymes (AOE) decreased slightly during storage, regardless of storage temperatures. Muscle antioxidative enzymes activities stored at $4{ }^{\circ} \mathrm{C}$ were higher than that stored at $20^{\circ} \mathrm{C}$. Laiwu pig's enzymes activities were significantly $(\mathrm{p}<0.01)$ higher than Large White's. The level of malondialdehyde is a direct expression of the grade of lipid oxidation in meat. In our study, the malondialdehyde contents increased after 6 days storage. However, malondialdehyde contents of Laiwu pig were significantly $(\mathrm{p}<0.01)$ lower than Large White's. A lower content of malondialdehyde corresponds to a lower oxidation of lipids. These results indicated the muscle antioxidative ability of Laiwu pig was higher than Large White pig. It also implied that antioxidative enzymes were involved in the essentials and deciding mechanisms of meat quality by quenching oxygen free radicals and inhibiting lipid oxidation in muscle. (Key Words: Pig, Superoxide Dismutase, Catalase, Glutathione Peroxidase, Malondialdehyde)
\end{abstract}

\section{INTRODUCTION}

Meat quality can be defined as a combination of the physical and chemical properties of fresh and processed meat. These properties are represented by the meat color, $\mathrm{pH}$ values, water-holding capacity, and cooking loss (van der Wal et al., 1997). Nowadays, antioxidant capacity of meat is also important. Lipid oxidation of meat may lead to decrease eating quality such as odor, flavor, tenderness and juiciness (Fernández et al., 1997). Lipid oxidation is the main non-microbial factor causing the quality deterioration of meat (Fernández et al., 1997; Pradhan et al., 2000; Hernández et al., 2004; Descalzo et al., 2005; Terevinto et al., 2010). Lipid oxidation affects the fatty acids, particularly polyunsaturated fatty acids (Fernández et al., 1997), and the oxidation of unsaturated fatty acids in biomembranes can lead to decreased fluidity of the biomembranes and disruption of the normal membrane structure and function (Dobretsov et al., 1977). So the lipid oxidation damages the integrity of biological membrane which would cut down the water-holding capacity. In

\footnotetext{
* Corresponding Author: Yong-Qing Zeng. Tel: +86-5388242478, Fax: +86-538-8241419, E-mail: yqzeng@sdau.edu.cn Submitted Jan. 9, 2012; Accepted Mar. 12, 2012; Revised Apr. 4, 2012
}

addition, oxidation may be linked to meat tenderness (Mercier et al., 2004; Rowe et al., 2004) and might play a role in controlling proteolytic activity of enzymes (Mercier et al., 2004).

The lipid oxidation degradation produces aldehydes, alcohols and other organic compounds that change the meat quality during the storage (Eriksson, 1982). Malondialdehyde (MDA) is one of aldehydes which produced during the lipid oxidation degradation. Also, MDA is thought to be a carcinogenic initiator, and therefore can affect the safety of the food (Fernández et al., 1997). So, MDA contents of meat are very important to lipid oxidation, and the relation between MDA content and lipid oxidation has aroused the interest of investigators (Fernández et al., 1997).

The oxidative stability of muscle is dependent on the balance between the activity of endogenous pro-oxidants (iron, copper, myoglobin, etc.) and antioxidants (antioxidant enzymes, glutathione, etc.) (Gopalakrishnan et al., 1999). Living cells against oxidative processes by several mechanisms of protection, including antioxidant enzymes such as superoxide dismutase (SOD), catalase (CAT) and glutathione peroxidase (GPx) (Daun and Åkesson, 2004; Hernández et al., 2004). In addition, SOD and CAT are coupled enzymes (Gatellier et al., 2004; Terevinto et al., 
2010). SOD plays an important role in protecting against damage (Chan and Decker, 1994), and decomposes superoxide anion $\left(\mathrm{O}_{2}^{-}\right)$to hydrogen peroxide $\left(\mathrm{H}_{2} \mathrm{O}_{2}\right)$ and CAT safely decomposes $\mathrm{H}_{2} \mathrm{O}_{2}$ to water (Gatellier et al., 2004; Mercier et al., 2004). GPx is considered the major peroxide-removing enzyme located in the cytosol (Chan and Decker, 1994; Decker and Xu, 1998). And GPx can decompose both $\mathrm{H}_{2} \mathrm{O}_{2}$ and lipoperoxides formed during lipid oxidation (Gatellier et al., 2004).

Laiwu pig is one of Chinese indigenous black pig breeds and is mainly reared in Shandong province. Previous research showed that SOD activity of Longissimus dorsi muscle in Laiwu pigs was significantly higher than that in Large White pig (Li et al., 2010). Otherwise, the GPx4 activity of Longissimus dorsi muscle in Laiwu pigs also was significantly higher than that in Large White pig (Chen et al., 2011). So, the purposes of this study were: i) to quantify and compare the major antioxidant enzymes (SOD, CAT and GPx) activities, and ii) to quantify and compare the lipid oxidation by measuring the MDA contents in porcine Longissimus dorsi muscle when stored over a period of six days ( 1 to $\mathrm{d} 6)$ at two different temperatures $\left(4^{\circ} \mathrm{C}\right.$ and $\left.20^{\circ} \mathrm{C}\right)$.

\section{MATERIALS AND METHODS}

\section{Animals and samples preparation}

Twelve pigs (Laiwu pig, $n=6$; Large White pig, $n=6$ ) were used in this experiment. All pigs were reared at Laiwu pig breeding farm at Laiwu city and were fed a commercial pig feed and water ad libitum. The pigs were handled according to the 'Regulations on Administration of Hog Slaughter' and 'Good manufacturing practice for pig slaughter (GB/T 19479-2004)'. All pigs were slaughtered at a local commercial abattoir (LIURUN SHIPIN Co., Ltd.) about 6 months of age following standard industrial procedures and the average carcass weight of the pigs was $80 \pm 5 \mathrm{~kg}$. The Longissimus dorsi muscles (whole lions of the right carcasses) were obtained from carcasses, and were sliced into 2-cm thickness chops perpendicular to the fiber direction. The chops were stored at two different temperatures $\left(4^{\circ} \mathrm{C}\right.$ and $20^{\circ} \mathrm{C}$ ) for 6 days $(1$ to $6 \mathrm{~d}$ ), and the samples stored $\left(20^{\circ} \mathrm{C}\right)$ in the dark. The activities of SOD, CAT and GPX, and MDA contents of the samples of each day were measured during storage.

\section{Assays of antioxidant enzyme activities}

A 0.4-g muscle sample was homogenized in a tissue homogenizer (ULTRA-TURRAX ${ }^{\circledR}$ T18 basic, IKA, Germany) with $3.6 \mathrm{ml}$ of $0.86 \% \mathrm{NaCl}$ for $3 \times 10 \mathrm{~s}$ at 23,000 rpm in an ice bath and the homogenate centrifuged at $4{ }^{\circ} \mathrm{C}$ for $15 \mathrm{~min}$ at $7,000 \times \mathrm{g}$. The supernatant was filtered through glass wool and used to determine antioxidant enzyme activities. Superoxide dismutase, catalase and glutathione peroxidase assay kits (Nanjing Jiancheng Bioengineering Institute, Jiangsu Province, China, http://www.njjcbio.com/) were used for the assay of SOD, CAT and GPx activities according to the manufacturer's instructions. One unit of SOD activity is defined as the amount of enzyme in each milliliter of the reaction solution at 50\% SOD inhibition at $37^{\circ} \mathrm{C}$. One unit of CAT activity is defined as the amount of enzyme in one milligram tissue protein consumption of 1 $\mu \mathrm{mol} \mathrm{H}_{2} \mathrm{O}_{2}$ per second at $37^{\circ} \mathrm{C}$. One unit of GPx activity is defined as the net amount of the enzyme capable of hydrolyzing $1 \mu \mathrm{mol}$ of GSH (Glutathione) per min at $37^{\circ} \mathrm{C}$.

\section{Assays of MDA contents}

The MDA assays kits (Nanjing Jiancheng Bioengineering Institute, Jiangsu Province, China, http://www.njjcbio.com/) were used to assay the MDA contents of Longissimus dorsi muscle of Laiwu pig and Large White pig. MDA can react with thiobarbituric acid (TBA), and obtaining a red pigment which have the maximum absorbance at $532 \mathrm{~nm}$. The MDA values were expressed as nmol/mg protein.

\section{Statistical analysis}

All values are reported as mean \pm standard error of mean (SEM) for three measurements on each muscle sample. The data were analyzed by the procedure Repeated Measures Analysis of Variance of Statistical Analysis Systems statistical software package (Version 9.2; SAS Inst., Inc., Cary, NC, USA). The correlations between the antioxidative enzymes activity and MDA content were characterized by the PROC CORR procedure of the SAS software. The p-value $<0.05$ was considered to be statistically significant.

\section{RESULTS}

\section{Changes in SOD activities during postmortem storage}

Data on the SOD activities of porcine muscles are presented in Table 1. From the table, it shows the storage temperatures significantly affected the SOD activity and the SOD activities of porcine muscles were decreased during storage days. The SOD activities of porcine Longissimus dorsi stored at $4^{\circ} \mathrm{C}$ were significantly $(\mathrm{p}<0.01)$ higher than that stored at $20^{\circ} \mathrm{C}$ (Table 1 ). The SOD activity of porcine muscle stored at $4^{\circ} \mathrm{C}$ decreased slowly when stored a period of 1 to 6 days. However, compared with stored at $4^{\circ} \mathrm{C}$, the decrease trend of SOD activity stored at $20^{\circ} \mathrm{C}$ was faster.

Furthermore, pig breeds also can affect the SOD activity; and Figure 1 shows the effects of pig breeds on the changes of SOD activities of muscle stored at $4^{\circ} \mathrm{C}$ (Figure 1A) and $20^{\circ} \mathrm{C}$ (Figure 1B). As shown in Figure 1 , the activity of SOD of Laiwu pigs was significantly $(p<0.01)$ higher than Large White's SOD activity when the muscles 
Table 1. SOD activity of porcine muscle stored at different days and temperatures

\begin{tabular}{llccccccc}
\hline \multirow{2}{*}{$\begin{array}{l}\text { Temperature } \\
\left({ }^{\circ} \mathrm{C}\right)\end{array}$} & \multirow{2}{*}{ Breed } & \multicolumn{6}{c}{ SOD activity (U/mg protein) during storage } & \multirow{2}{*}{ Average $^{\text {a }}$} \\
\cline { 3 - 8 }$n$ & Laiwu pig & $60.12 \pm 2.85$ & $57.04 \pm 2.10$ & $52.57 \pm 2.80$ & $52.33 \pm 2.79$ & $48.76 \pm 2.35$ & $46.80 \pm 2.39$ & $37.98 \pm 3.47^{\mathrm{A}}$ \\
& Large white & $26.51 \pm 3.11$ & $23.76 \pm 2.75$ & $23.33 \pm 2.14$ & $21.19 \pm 2.14$ & $20.10 \pm 1.90$ & $16.48 \pm 2.26$ \\
20 & Laiwu pig & $55.89 \pm 2.84$ & $53.69 \pm 2.75$ & $50.01 \pm 2.32$ & $48.91 \pm 1.97$ & $44.45 \pm 2.20$ & $42.99 \pm 2.18$ & $31.91 \pm 4.32^{\mathrm{B}}$ \\
& Large white & $15.68 \pm 1.26$ & $14.36 \pm 1.17$ & $11.33 \pm 0.46$ & $13.13 \pm 1.27$ & $10.61 \pm 0.47$ & $9.71 \pm 1.51$ & \\
Average $^{\mathrm{b}}$ & & $39.55 \pm 4.13^{\mathrm{A}}$ & $37.11 \pm 4.02^{\mathrm{AB}}$ & $34.31 \pm 3.93^{\mathrm{B}}$ & $33.89 \pm 3.68^{\mathrm{B}}$ & $30.89 \pm 3.53^{\mathrm{BC}}$ & $29.22 \pm 3.45^{\mathrm{C}}$ \\
\hline
\end{tabular}

Values in each cell are mean $\pm \operatorname{SEM}(n=6)$.

${ }^{a}$ Values bearing different superscripts differ significantly in two different storage temperatures $(\mathrm{p}<0.01)$.

${ }^{\mathrm{b}}$ Values bearing different superscripts differ significantly in different storage times $(\mathrm{p}<0.01)$.
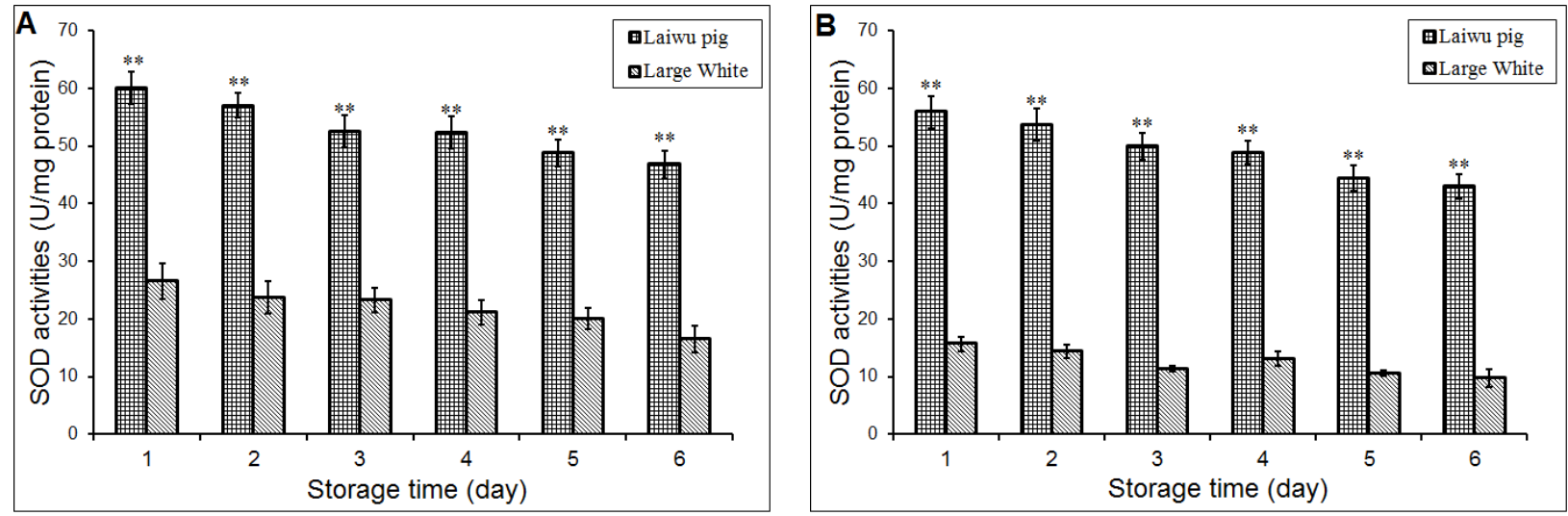

Figure 1. Comparison of muscle SOD activity. The muscle samples of Laiwu pig and Large White pig stored at $4{ }^{\circ} \mathrm{C}(\mathrm{A})$ and $20^{\circ} \mathrm{C}(\mathrm{B})$ for 1-6 days. Each value is represented as the means \pm SEM $(n=6)$. Asterisks indicate differences that are statistically significant $(* * \mathrm{p}<0.01)$.

samples stored at two temperatures (Figure 1). Compared with Large White pig, Laiwu pig as a Chinese indigenous pig breed showed strongly SOD activity, and it suggested that Laiwu pig can more effectively inhibit lipid oxidation and have a long shelf-life after slaughtered.

\section{Changes in CAT activities during postmortem storage}

The changes in CAT activity were deceased drastically during storage and the data are presented in Table 2. Storage temperature and time significantly affected the CAT activity. The CAT activity of porcine Longissimus dorsi stored at $4^{\circ} \mathrm{C}$ was significantly $(\mathrm{p}<0.01)$ higher than that stored at $20^{\circ} \mathrm{C}$ and there was significantly changed in CAT activity of porcine Longissimus dorsi at different storage days. On the other hand, pig breed also can affect the CAT activity (Figure 2). Laiwu pig as a Chinese native breed shows higher CAT activity when the porcine muscles stored at $4^{\circ} \mathrm{C}$ and $20^{\circ} \mathrm{C}$. Muscle CAT activity was significantly $(\mathrm{p}<0.05)$ higher in Laiwu pig than in Large White pig when the muscles stored at $4{ }^{\circ} \mathrm{C}$ and $20^{\circ} \mathrm{C}$ (Figure 2). Like the Laiwu pig, the CAT activity of Large White pig was also higher stored at $4{ }^{\circ} \mathrm{C}$ than that stored at $20^{\circ} \mathrm{C}$.

\section{Changes in GPx activities during postmortem storage}

Table 3 shows the GPx activity when the muscles stored at different time. The activity of GPx enzyme decreased

Table 2. CAT activity of porcine muscle stored at different days and temperatures

\begin{tabular}{|c|c|c|c|c|c|c|c|c|}
\hline \multirow{2}{*}{$\begin{array}{l}\text { Temperature } \\
\left({ }^{\circ} \mathrm{C}\right)\end{array}$} & \multirow{2}{*}{ Breed } & \multicolumn{6}{|c|}{ CAT activity (U/mg protein) during storage } & \multirow{2}{*}{ Average $^{a}$} \\
\hline & & $1 \mathrm{~d}$ & $2 \mathrm{~d}$ & $3 \mathrm{~d}$ & $4 \mathrm{~d}$ & $5 \mathrm{~d}$ & $6 \mathrm{~d}$ & \\
\hline \multirow[t]{2}{*}{4} & Laiwu pig & $4.83 \pm 0.80$ & $3.83 \pm 0.79$ & $2.97 \pm 0.57$ & $2.93 \pm 0.51$ & $2.59 \pm 0.42$ & $1.94 \pm 0.44$ & $2.81 \pm 0.64^{\mathrm{A}}$ \\
\hline & Large white & $3.25 \pm 0.63$ & $2.33 \pm 0.28$ & $2.39 \pm 0.20$ & $1.95 \pm 0.31$ & $1.93 \pm 0.31$ & $1.41 \pm 0.15$ & \\
\hline \multirow[t]{2}{*}{20} & Laiwu pig & $3.21 \pm 0.59$ & $2.39 \pm 0.57$ & $2.18 \pm 0.59$ & $1.91 \pm 0.46$ & $1.50 \pm 0.44$ & $1.23 \pm 0.45$ & $1.90 \pm 0.73^{\mathrm{B}}$ \\
\hline & Large white & $2.41 \pm 0.35$ & $1.90 \pm 0.34$ & $1.68 \pm 0.22$ & $1.38 \pm 0.25$ & $1.13 \pm 0.22$ & $0.79 \pm 0.14$ & \\
\hline Average $^{b}$ & & $3.42 \pm 0.34^{\mathrm{A}}$ & $2.61 \pm 0.29^{\mathrm{B}}$ & $2.31 \pm 0.24^{\mathrm{B}}$ & $2.04 \pm 0.22^{\mathrm{B}}$ & $1.79 \pm 0.35^{\mathrm{BC}}$ & $1.34 \pm 0.18^{\mathrm{C}}$ & \\
\hline
\end{tabular}

Values in each cell are mean $\pm \operatorname{SEM}(n=6)$.

${ }^{a}$ Values bearing different superscripts differ significantly in two different storage temperatures $(\mathrm{p}<0.01)$.

${ }^{\mathrm{b}}$ Values bearing different superscripts differ significantly in different storage times $(\mathrm{p}<0.01)$. 

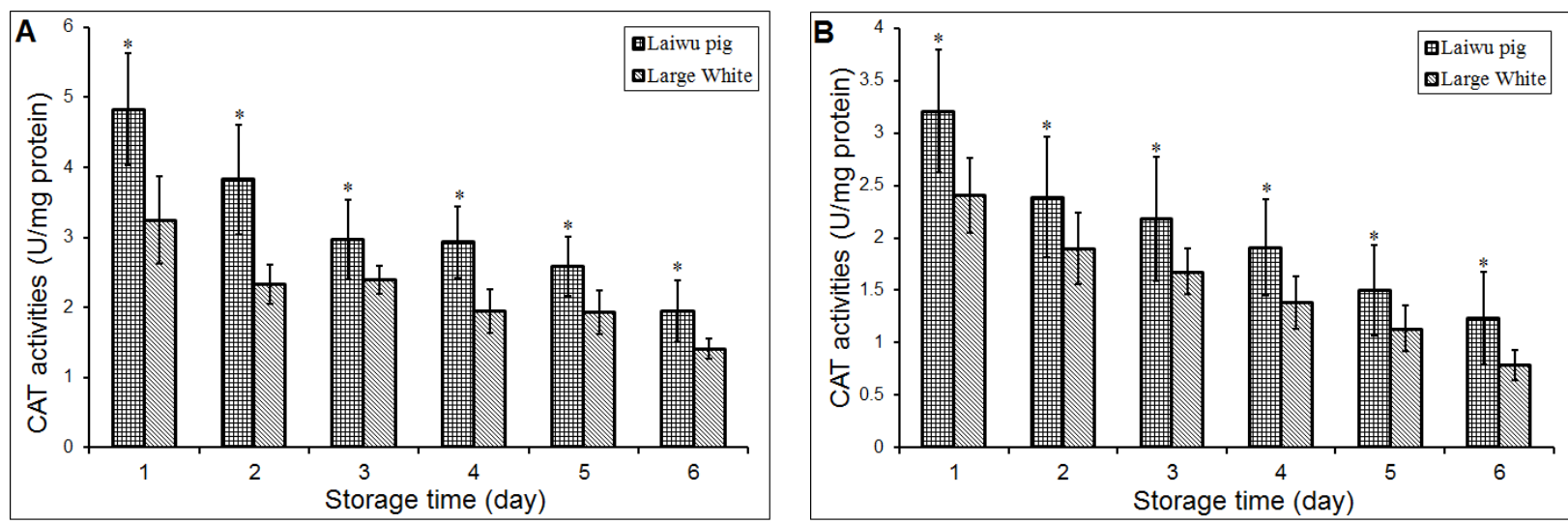

Figure 2. Comparison of muscle CAT activity. The muscle samples of Laiwu pig and Large White pig stored at $4{ }^{\circ} \mathrm{C}(\mathrm{A})$ and $20^{\circ} \mathrm{C}(\mathrm{B})$ for 1-6 days. Each value is represented as the means $\pm \operatorname{SEM}(n=6)$. Asterisks indicate differences that are statistically significant $(* \mathrm{p}<0.05)$.

drastically during storage. The storage days significantly affected the GPx activity from Table 3. And the muscle GPx activities stored at $4^{\circ} \mathrm{C}$ were significantly $(\mathrm{p}<0.01)$ higher than that stored at $20^{\circ} \mathrm{C}$ in the two pig breeds.

In addition, effects of pig breed on the changes in GPx activities of Longissimus dorsi muscle during storage were showed in Figure 3. In Laiwu pigs, the GPx activities decreased drastically when the muscles stored at $20^{\circ} \mathrm{C}$. Compared with stored at $20^{\circ} \mathrm{C}$, however, the GPx activities in Laiwu pigs were only slightly affected during storage at $4^{\circ} \mathrm{C}$. Furthermore, muscle GPx activity in Laiwu pig was significantly $(\mathrm{p}<0.01)$ higher than that in Large White pig at the two storage temperatures $\left(4^{\circ} \mathrm{C}\right.$ and $\left.20^{\circ} \mathrm{C}\right)$.

\section{Comparative analysis in muscle MDA contents}

Oxidation in meat usually leads to deterioration in quality. Lipid oxidation values were measured by MDA content in this experiment. During meat maturation for 6

Table 3. GPx activity of porcine muscle stored at different days and temperatures

\begin{tabular}{|c|c|c|c|c|c|c|c|c|}
\hline \multirow{2}{*}{$\begin{array}{l}\text { Temperature } \\
\left({ }^{\circ} \mathrm{C}\right)\end{array}$} & \multirow{2}{*}{ Breed } & \multicolumn{6}{|c|}{ GPx activity (U/mg protein) during storage } & \multirow{2}{*}{ Average $^{a}$} \\
\hline & & $1 \mathrm{~d}$ & $2 \mathrm{~d}$ & $3 \mathrm{~d}$ & $4 \mathrm{~d}$ & $5 \mathrm{~d}$ & $6 \mathrm{~d}$ & \\
\hline \multirow[t]{2}{*}{4} & Laiwu pig & $9.91 \pm 0.44$ & $9.33 \pm 0.49$ & $8.24 \pm 0.53$ & $7.77 \pm 0.62$ & $5.61 \pm 0.97$ & $4.76 \pm 1.17$ & $6.06 \pm 0.94^{\mathrm{A}}$ \\
\hline & Large white & $7.02 \pm 1.35$ & $4.49 \pm 1.04$ & $2.43 \pm 0.25$ & $3.18 \pm 0.81$ & $2.43 \pm 0.75$ & $1.99 \pm 0.79$ & \\
\hline \multirow[t]{2}{*}{20} & Laiwu pig & $8.77 \pm 0.52$ & $7.06 \pm 0.71$ & $5.92 \pm 0.72$ & $5.43 \pm 0.83$ & $4.26 \pm 0.89$ & $3.64 \pm 0.99$ & $4.29 \pm 1.13^{\mathrm{B}}$ \\
\hline & Large white & $4.45 \pm 1.05$ & $2.33 \pm 0.62$ & $2.21 \pm 0.43$ & $1.81 \pm 0.26$ & $1.29 \pm 0.20$ & $0.84 \pm 0.28$ & \\
\hline Average $^{b}$ & & $7.54 \pm 0.61^{\mathrm{A}}$ & $5.80 \pm 0.65^{\mathrm{B}}$ & $4.71 \pm 0.52^{\mathrm{C}}$ & $4.55 \pm 0.57^{\mathrm{CD}}$ & $3.40 \pm 0.52^{\mathrm{D}}$ & $2.81 \pm 0.51^{\mathrm{E}}$ & \\
\hline
\end{tabular}

Values in each cell are mean $\pm \operatorname{SEM}(n=6)$.

${ }^{a}$ Values bearing different superscripts differ significantly in two different storage temperatures $(\mathrm{p}<0.01)$.

${ }^{\mathrm{b}}$ Values bearing different superscripts differ significantly in different storage times $(\mathrm{p}<0.01)$.
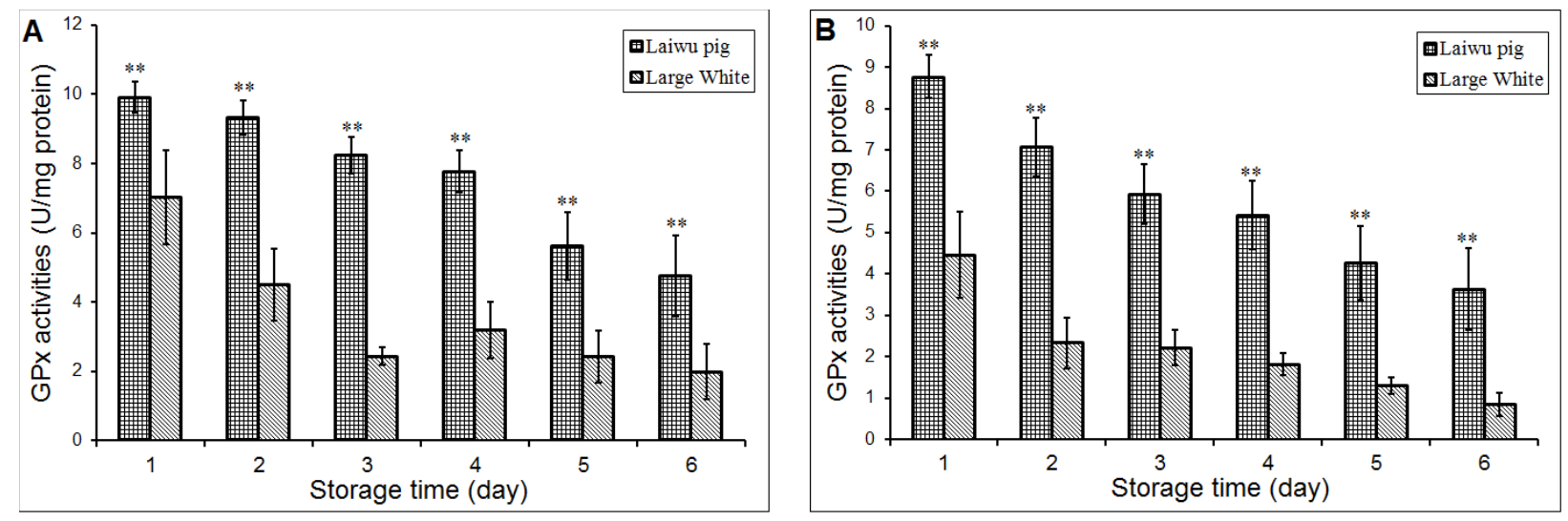

Figure 3. Comparison of muscle GPx activity. The muscle samples of Laiwu pig and Large White pig stored at $4{ }^{\circ} \mathrm{C}(\mathrm{A})$ and $20^{\circ} \mathrm{C}(\mathrm{B})$ for 1-6 days. Each value is represented as the means $\pm \operatorname{SEM}(n=6)$. Asterisks indicate differences that are statistically significant $(* * \mathrm{p}<0.01)$. 
Table 4. MDA content of porcine muscle stored at different days and temperatures

\begin{tabular}{lllcccccc}
\hline \multirow{2}{*}{$\begin{array}{c}\text { Temperature } \\
\left({ }^{\circ} \mathrm{C}\right)\end{array}$} & \multirow{2}{*}{ Breed } & \multicolumn{6}{c}{ MDA content (nmol/mg protein) during storage } & \multirow{2}{*}{ Average $^{\text {a }}$} \\
\cline { 3 - 8 } & & $1 \mathrm{~d}$ & $2 \mathrm{~d}$ & $3 \mathrm{~d}$ & $4 \mathrm{~d}$ & $5 \mathrm{~d}$ & $6 \mathrm{~d}$ & \\
\hline 4 & Laiwu pig & $0.11 \pm 0.016$ & $0.16 \pm 0.018$ & $0.18 \pm 0.017$ & $0.21 \pm 0.016$ & $0.24 \pm 0.023$ & $0.27 \pm 0.035$ & $0.25 \pm 0.024^{\mathrm{B}}$ \\
& Large white & $0.14 \pm 0.002$ & $0.30 \pm 0.002$ & $0.34 \pm 0.007$ & $0.37 \pm 0.005$ & $0.41 \pm 0.006$ & $0.45 \pm 0.009$ & \\
& Laiwu pig & $0.15 \pm 0.019$ & $0.17 \pm 0.002$ & $0.21 \pm 0.017$ & $0.22 \pm 0.016$ & $0.26 \pm 0.021$ & $0.31 \pm 0.026$ & $0.33 \pm 0.018^{\mathrm{A}}$ \\
& Large white & $0.30 \pm 0.024$ & $0.37 \pm 0.012$ & $0.42 \pm 0.011$ & $0.47 \pm 0.004$ & $0.54 \pm 0.022$ & $0.65 \pm 0.023$ & \\
Average $^{\mathrm{b}}$ & & $0.17 \pm 0.018^{\mathrm{D}}$ & $0.25 \pm 0.020^{\mathrm{C}}$ & $0.29 \pm 0.019^{\mathrm{B}}$ & $0.32 \pm 0.023^{\mathrm{B}}$ & $0.36 \pm 0.025^{\mathrm{AB}}$ & $0.42 \pm 0.033^{\mathrm{A}}$ & \\
\hline
\end{tabular}

Values in each cell are mean $\pm \operatorname{SEM}(n=6)$.

${ }^{a}$ Values bearing different superscripts differ significantly in two different storage temperatures $(\mathrm{p}<0.01)$.

${ }^{\mathrm{b}}$ Values bearing different superscripts differ significantly in different storage times $(\mathrm{p}<0.01)$.
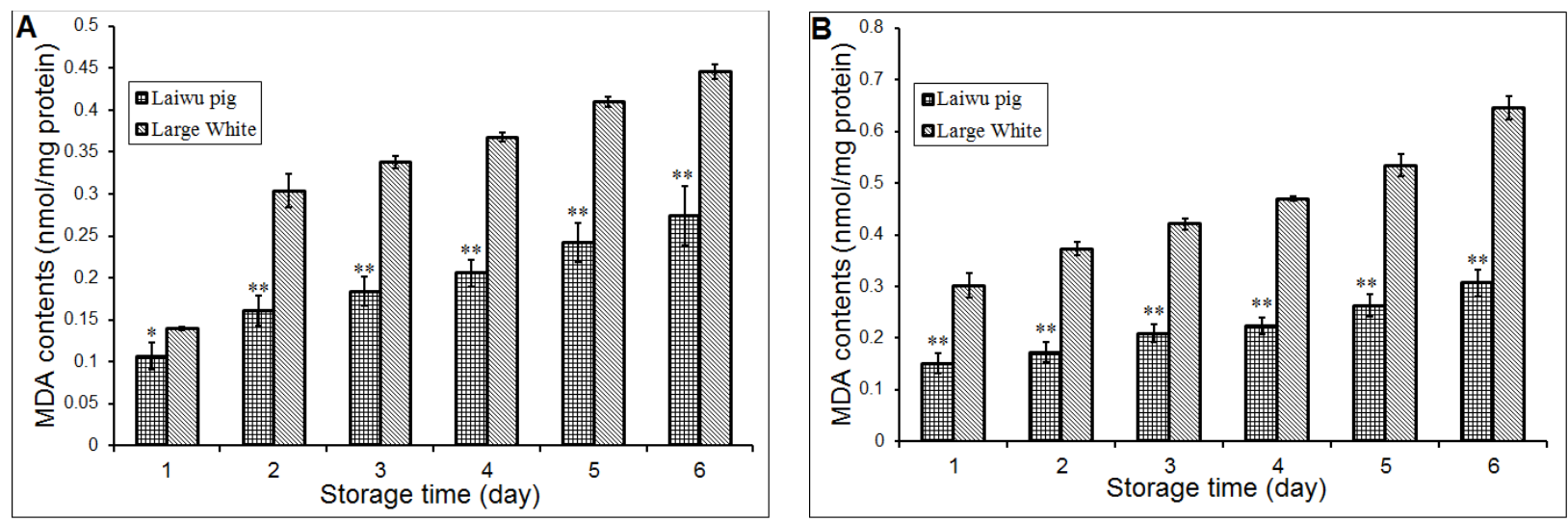

Figure 4. Comparison of muscle MDA content. The muscle samples of Laiwu pig and Large White pig stored at $4{ }^{\circ} \mathrm{C}(\mathrm{A})$ and $20^{\circ} \mathrm{C}(\mathrm{B})$ for 1-6 days. Each value is represented as the means \pm SEM $(n=6)$. Asterisks indicate differences that are statistically significant $(* \mathrm{p}<0.05, * * \mathrm{p}<0.01)$.

days, there was an increase in MDA content and data on the MDA contents of the muscles are presented in Table 4. As shown in Table 4, the MDA contents were increased drastically during storage. The MDA contents were significantly affected by storage times; and the MDA contents stored at $4^{\circ} \mathrm{C}$ were significantly $(p<0.01)$ lower than that stored at $20^{\circ} \mathrm{C}$. Also, pig breed is one important factor on the MDA content of porcine Longissimus dorsi muscle during storage. The MDA contents of Large White pig were significantly $(\mathrm{p}<0.01)$ higher than Laiwu pigs when the muscles stored at $4^{\circ} \mathrm{C}$ and $20^{\circ} \mathrm{C}$ (Figure 4).

\section{Relationship between antioxidant enzymes and MDA contents}

Measurement of the antioxidant enzyme activity showed a better protection to the lipid oxidation. So, we analyzed the correlation between antioxidant enzyme activity and MDA content (Table 5). The results showed negative correlations were obtained between antioxidant enzyme activities and MDA contents, especially the correlation between SOD activity and MDA content during storage time $(r=-0.75 ; \mathrm{p}<0.0001)$.

Antioxidant defenses in meat are composed by nonenzymatic system like vitamin $\mathrm{E}$ and enzymatic system like
SOD, CAT and GPx (Descalzo and Sancho, 2008). After the death of pigs, the enzymatic system probably acts to prevent the lipid oxidation in the meat maturation. Our results show the MDA content increase with increasing storage time, and antioxidant enzymes play an important role in protecting lipid oxidation.

\section{DISCUSSION}

Oxidation rate of postmortem muscle depends on the anti-oxidative capacity in the animal; and also, oxidation of muscle components postmortem can be retarded by the action of endogenous antioxidative enzymes, especially SOD, CAT and GPx, which seem to be relatively stable during refrigerated storage. Also Renerre et al. (1996) found that SOD activity in Psoas major was higher than that in

Table 5. Correlation analysis between AOE activity and MDA content

\begin{tabular}{lcr}
\hline \multirow{2}{*}{ AOE activity } & \multicolumn{2}{c}{ MDA content } \\
\cline { 2 - 3 } & \multicolumn{1}{c}{$r$} \\
\hline SOD & -0.75 & \multicolumn{1}{c}{$\mathrm{p}$} \\
CAT & -0.49 & 0.0001 \\
GPx & -0.73 & $<0.0001$ \\
\hline
\end{tabular}


Longissimus lumborum. These results indicated that there is a natural protection which decreases the deleterious effects of oxy radicals. The reported results were in accordance with previously published data on these varieties. In our results, during 6 days storage at $20^{\circ} \mathrm{C}$, muscle SOD activity of Large White pig decreased significantly $(\mathrm{p}<0.01)$ between d 1 (15.68 U/mg protein) and d $6(9.71 \mathrm{U} / \mathrm{mg}$ protein) postmortem. Similar to this result, Laiwu pig's muscle SOD activity decreased significantly $(\mathrm{p}<0.01)$ from $55.89 \mathrm{U} / \mathrm{mg}$ protein to $42.99 \mathrm{U} / \mathrm{mg}$ protein during 6 days storage (Figure 1).

Previous research reported that exogenously added CAT to beef samples failed to prevent lipid oxidation (Pradhan et al., 2000). Descalzo et al., (2000) found CAT activity in Psoas major muscle in beef still remained stable after 9 days storage. And, Renerre et al. (1996) also found CAT activity in Diaphragma muscle didn't change significantly after 8 days refrigerated storage, but it was higher $(\mathrm{p}<0.05)$ than that in another three muscles (Psoas major, Longissimus lumborum and Tensor fasciae latae). In our results, however, CAT activities significantly changes $(\mathrm{p}<0.05)$ during storage at two different temperatures; Laiwu pig as a Chinese indigenous pig breed, and its muscles shows higher CAT activity which was significantly higher than Large White pig during storage at $4^{\circ} \mathrm{C}$ and $20^{\circ} \mathrm{C}$ (Figure 2).

GPx activity in meat samples is controversial (Descalzo and Sancho, 2008). The GPx activity was strongly affected by the diet in Charolais cattle (Gatellier et al., 2004), and also influenced by the degree of unsaturation of the diet in chicken (Maraschiello et al., 1999). However, in our results, there was significantly $(\mathrm{p}<0.01)$ decrease in GPx activity in porcine Longissimus dorsi muscle in Laiwu pigs and Large White pigs. The muscle GPx activity was affected by pig breeds and storage temperatures. Muscle GPx activity in Laiwu pigs was significantly $(\mathrm{p}<0.01)$ higher than that in Large White pig at the same storage temperature. On the other hand, muscle GPx activity of Laiwu pigs decreased significantly $(\mathrm{p}<0.01)$ between $\mathrm{d} 1(8.77 \mathrm{U} / \mathrm{mg}$ protein $)$ and d 6 (3.64 U/mg protein) postmortem stored at $20^{\circ} \mathrm{C}$, also Large White's GPx activity between d 1 (4.45 U/mg protein) and d $6(0.84 \mathrm{U} / \mathrm{mg}$ protein $)$. There are the same results when the muscles stored at $4{ }^{\circ} \mathrm{C}$ (Figure 3 ).

MDA is the principal and most studied product of polyunsaturated fatty acids per-oxidation. The measurement of MDA is important for the assessment of oxidative stress as MDA has been used as a biomarker of lipid oxidation for more than 30 years (Del Rio et al., 2005). In the present research, the muscle MDA contents were significantly $(p<0.01)$ affected by pig breed and storage temperature. The Laiwu pig's muscle MDA contents were lower than large white's; and also, muscle MDA contents stored at $4{ }^{\circ} \mathrm{C}$ were lower than that stored at $20^{\circ} \mathrm{C}$ (Figure 4).
Recently, Xia et al. (2009) reported there was a significantly $(\mathrm{p}<0.05)$ increase in TBARS when the porcine Longissimus dorsi muscle subjected to multiple freeze-thaw cycles, and this indicated an increase in the lipid oxidation. On the other hand, the apparent relationship between protein carbonyls and TBARS indicated a strong likelihood that some dicarbonyl compounds derived from lipid oxidation, notably MDA, formed complexes with proteins (Li and King, 1996; Xia et al., 2009). In this work, we found that there was significantly $(\mathrm{p}<0.01)$ increase of the muscle MDA contents during storage, and it indicated an increase in the lipid oxidation in porcine Longissimus dorsi muscle (Figure 4). In addition, the development of lipid oxidation may vary according to the age, muscle type, breed and feeding regime (Descalzo and Sancho, 2008). The lipid oxidation produces MDA; and the Longissimus dorsi of Laiwu pig breed shows lower MDA content than Large White. So, the lower MDA content of Laiwu pig reflects there was lower level of lipid oxidation in our experiment. Anyway, changes in MDA content could have occurred during storage at the two different temperatures $\left(4^{\circ} \mathrm{C}\right.$ and 20 $\left.{ }^{\circ} \mathrm{C}\right)$.

SOD, CAT and GPx are very important antioxidative enzymes which can prevent oxidation reactions to improve meat quality and extend the shelf-life. In our results, there will be a strongly antioxidative capacity, if there are higher enzyme's activities of SOD, CAT and GPx, and lower MDA contents. So, improving the antioxidative enzyme's activity of muscle by selective breeding is very important to the meat quality and safety.

\section{CONCLUSIONS}

In summary, this study evaluated the changes in the main antioxidative enzymes activity and MDA contents in pork meat during storage. These results indicate that the enzyme's activity of SOD, CAT and GPx was decrease during the storage at two different temperatures, and the MDA contents were increase during the storage. There were the higher antioxidative enzymes activities and lower MDA contents when the pork meat stored at $4^{\circ} \mathrm{C}$. It suggested $4^{\circ} \mathrm{C}$ is more suitable for meat storage compared with $20^{\circ} \mathrm{C}$. However, the antioxidative capacity of the Chinese native pig, Laiwu pig, is stronger than Large White's at all the storage time. In addition, antioxidant enzymes activities were negative correlated with the MDA contents. These results indicate pork muscle samples with higher antioxidant enzymes activity would be less susceptible to lipid oxidation.

\section{ACKNOWLEDGEMENTS}

We express gratitude to Shu-Dong Wei (Bureau of 
Livestock of Laiwu City) for supplying porcine muscles. And we also thank Qiang-Ling Zhang, Xue-Ming $\mathrm{Xu}$, Jiang-Hua Liu for assistance with experiments. The present study was supported by the National Project for Breeding Transgenic Pigs of China (No. 2008ZX08006-002), the National High-tech Research and Development Program of China (863 Program) (No. 2008AA101008), Shandong Province Agricultural Animal Breeding Project of China (No. 2007LZ013), and the Natural Science Foundation of Shandong Province of China (No. Y2008D32).

\section{REFERENCES}

Chan, K. M. and E. A. Decker. 1994. Endogenous skeletal muscle antioxidants. Crit. Rev. Food Sci. Nutr. 34:403-426.

Chen, W., Y. Zeng, J. Cui, Q. Chen, J. Du, L. Yang, Y. Hu, Y. Song and Y. Qian. 2011. Effects of phospholipid hydroperoxide glutathione peroxidase mRNA expression on meat quality of M.Longissimus dorsi in pigs. Eur. Food Res. Technol. 232:433440.

Daun, C. and B. Åkesson. 2004. Comparison of glutathione peroxidase activity, and of total and soluble selenium content in two muscles from chicken, turkey, duck, ostrich and lamb. Food Chem. 85:295-303.

Decker, E. A. and Z. Xu. 1998. Minimizing rancidity in muscle foods. Food Technol. 52:54-59.

Del Rio, D., A. J. Stewart and N. Pellegrini. 2005. A review of recent studies on malondialdehyde as toxic molecule and biological marker of oxidative stress. Nutr. Metab. Cardiovasc. Dis. 15:316-328.

Descalzo, A. M., E. M. Insani, A. Biolatto, A. M. Sancho, P. T. García, N. A. Pensel and J. A. Josifovich. 2005. Influence of pasture or grain-based diets supplemented with vitamin $\mathrm{E}$ on antioxidant/oxidative balance of Argentine beef. Meat Sci. 70: $35-44$.

Descalzo, A. M., E. M. Insani, A. Eyherabide, S. M. Guidi and N. A. Pensel. 2000. Antioxidant enzymes activity in Psoas major beef muscle from different production systems. In: In Proceedings of the 46th international congress of meat science and technology. 2:560-561.

Descalzo, A. M. and A. M. Sancho. 2008. A review of natural antioxidants and their effects on oxidative status, odor and quality of fresh beef produced in Argentina. Meat Sci. 79:423436.

Dobretsov, G. E., T. A. Borschevskaya, V. A. Petrov and Y. A. Vladimirov. 1977. The increase of phospholipid bilayer rigidity after lipid peroxidation. FEBS Lett. 84:125-128.
Eriksson, C. E. 1982. Lipid oxidation catalysts and inhibitors in raw materials and processed foods. Food Chem. 9:3-19.

Fernández, J., J. A. Pérez-Álvarez and J. A. Fernández-López. 1997. Thiobarbituric acid test for monitoring lipid oxidation in meat. Food Chem. 59:345-353.

Gatellier, P., Y. Mercier and M. Renerre. 2004. Effect of diet finishing mode (pasture or mixed diet) on antioxidant status of Charolais bovine meat. Meat Sci. 67:385-394.

Gopalakrishnan, J., E. A. Decker and W. J. Means. 1999. Antioxidant activity of mechanically separated pork extracts. Meat Sci. 52:101-110.

Hernández, P., L. Zomeño, B. Ariño and A. Blasco. 2004. Antioxidant, lipolytic and proteolytic enzyme activities in pork meat from different genotypes. Meat Sci. 66:525-529.

Li, H., Y. Zeng, S. Wei, Q. Chen, Y. Song, Y. Qian, B. Dong and Z. Cui. 2010 Changes of superoxide dismutase activity and malondialdehyde level in postmortem muscle and their association with meat quality in pigs. Acta Veterinaria et Zootechnica Sinica 41:257-261.

Li, S. J. and A. J. King. 1996. Lipid oxidation and myosin denaturation in dark chicken meat. J. Agric. Food Chem. 44: 3080-3084.

Maraschiello, C., C. Sarraga and J. A. Garcia Regueiro. 1999. Glutathione peroxidase activity, TBARS, and $\alpha$-tocopherol in meat from chickens fed different diets. J. Agric. Food Chem. 47:867-872.

Mercier ,Y., P. Gatellier and M. Renerre. 2004. Lipid and protein oxidation in vitro, and antioxidant potential in meat from Charolais cows finished on pasture or mixed diet. Meat Sci. 66:467-473.

Pradhan, A. A., K. S. Rhee and P. Hernández. 2000. Stability of catalase and its potential role in lipid oxidation in meat. Meat Sci. 54:385-390.

Renerre, M., F. Dumont and P. Gatellier. 1996. Antioxidant enzyme activities in beef in relation to oxidation of lipid and myoglobin. Meat Sci. 43:111-121.

Rowe, L. J., K. R. Maddock, S. M. Lonergan and E. HuffLonergan. 2004. Oxidative environments decrease tenderization of beef steaks through inactivation of $\mu$-calpain. J. Anim. Sci. 82:3254-3266.

Terevinto, A., A. Ramos, G. Castroman, M. C. Cabrera and A. Saadoun. 2010. Oxidative status, in vitro iron-induced lipid oxidation and superoxide dismutase, catalase and glutathione peroxidase activities in rhea meat. Meat Sci. 84:706-710.

van der Wal, P. G., B. Engel and B. Hulsegge. 1997. Causes for variation in pork quality. Meat Sci. 46:319-327.

Xia, X., B. Kong, Q. Liu and J. Liu. 2009. Physicochemical change and protein oxidation in porcine Longissimus dorsi as influenced by different freeze-thaw cycles. Meat Sci. 83:239245. 